In particular, it was established that criminal law science identifies three approaches to understanding property as a generic object of crimes against property, according to which property is proposed to be understood as an economic category, a legal category, and an economic and legal phenomenon.

It is established that supporters of the first approach believe that crimes against property primarily impinge on property as a legal category, in other words, on the right to property. A fundamentally different position is consistently upheld by representatives of the second direction, in whose opinion, crimes against property impinge primarily on property as part of economic relations, the basis of the economic independence of the state.

At the same time, it is stated that the third position regarding the understanding of the generic object of crimes against property has been formed in criminal law science, supporters of which insist that in the criminal law aspect property should be considered comprehensively - taking into account both economic and legal understanding property. It is concluded that when formulating the definition of a generic object of crimes against property, it is necessary to apply an integrated economic and legal approach.

According to the results of writing the article, the generic object of crimes provided for by Section VI of the Special Part of the Criminal Code of Ukraine is proposed to understand the legal relations of property as an economic category, which gives the owner or legal owner rights to property, and which: and disposition of property or other property or obligations of rights provided by law; b) he exercises in accordance with the law at his discretion and in his own interests, regardless of the will of other persons.

Key words: generic object property, property right, property rights, rights of obligation, owner, legal owner.

DOI https://doi.org/10.33766/2524-0323.87.156-166

УДК 343.575 (477)

О. В. Одинцова,

кандидат юридичних наук, старший викладач кафедри кримінально-правових дисциплін

Луганського державного університету внутрішніх справ імені Е. О. Дідоренка (м. Сєвєродонецьк, Україна)

e-mail: doslidnuk.lg.nik@gmail.com

iDhttps://orcid.org/0000-0003-3864-228X

\title{
ДО ПИТАННЯ ЩОДО ДЕКРИМІНАЛІЗАЦІЇ ОБІГУ КАНАБІСУ В НЕЗНАЧНИХ РОЗМІРАХ
}

Статтю присвячено аналізу підстави та приводів декриміналізації незаконного виробництва, виготовлення, придбання, зберігання, перевезення та пересилання канабісу без мети збуту за відсутності кваліфікуючих ознак, передбачених ч. ч. 2 та 3 ст. 309 КК України.

Наведено аргументи на користь позиції, що в сучасних умовах протидія незаконному обігу канабісу без мети збуту кримінально-правовими засобами потребує удосконалення. Пропонується декриміналізувати назаконні дії 3 канабісом в незначних розмірах і передбачити за них адміністративну відповідальність за ст. 44 КУпАП за умов, що в діях винної особи відсутні такі кваліфікуючі ознаки, передбачені ч. ч. 2 та 3 ст. 309 КК України, як вчинення цих

() Одинцова О. В., 2019 
дій за попередньою змовою групою осіб; протягом року після засудження за ст. 309 КК України; із залученням неповнолітнього.

Ключові слова: наркотичні засоби; обіг канабісу; канабіс у незначних розмірах; незаконне виробництво, виготовлення, придбання, зберігання, перевезення чи пересилання канабісу без мети збуту; декриміналізація.

Постановка проблеми. Аналіз законодавства у сфері протидії незаконному обігу наркотиків дозволяє стверджувати, що фактично на сьогодні в Україні надається перевага силовим стереотипам розв'язання проблеми, пов'язаних із вживанням наркотичних засобів. У той же час Стратегія державної політики щодо наркотиків на період до 2010 року [1] наголошує на необхідності переходу від карального, кримінально-правового спрямування антинаркотичних заходів до лікувально-профілактичних i саме їх визнає найбільш плідними в контексті подолання наркоманії.

У той же час слід зазначити, що в Україні поступово змінюється ставлення громадськості до проблеми вживання канабісу як у медичних, так і немедичних цілях. Зокрема вже 15 років поспіль у Києві традиційно проходять «Конопляні марші свободи». Організатори цих заходів висувають зокрема й вимоги щодо легалізації канабісу та лікарських засобів на його основі в медичній практиці та «збільшення до об'єктивно виправданої порогової кількості канабісу (марихуани), що встановлює кримінальну відповідальність за зберігання без мети збуту» [2]. Їхні вимоги багато в чому збігаються за змістом із державною політикою низки (але не всіх) країн світу у сфері обігу канабісу, у яких намітилась тенденція до послаблення заборони на вживання канабісу без мети збуту. Станом на січень 2019 року в низці країн Європи, Америки, Азії, у 33 штатах США дозволено використання канабісу в медичних цілях. В Уругваї, декількох штатах США і Канаді канабіс легалізований повністю [3].

Крім того, відповідно до ч. 1 ст. 23-1 Закону України «Про звернення громадян» у засобах масової комунікації функціонують платформи громадських ініціатив, які збирають голоси громадян України за декриміналізацію марихуани, внесення змін до ст. 309 Кримінального кодексу України (далі - КК України) у бік пом'якшення покарань [4]. 3 серпня 2015 року і до сьогодні на сайті Офіційного інтернет-представництва Президента України регулярно реєструються електронні петиції з вимогами легалізації або декриміналізації марихуани (більше 15 електронних петицій) [5]. I хоча вони ще не набирають передбачені ч. 11 ст. 23-1 Закону України «Про звернення громадян» 25 тисяч підписів громадян для розгляду їх по суті, проте намічається тенденція зростання підписів громадян на підтримку цієї вимоги. Так за 2015-2017 рр. лише дві електронні петиції із 15 були підписані більше ніж тисячею громадян. Електронну петицію від 09.10.2018 року підписали вже 6889 громадян. Проте у 2019 році необхідну кількість голосів набрала електронна петиція, зареєстрована на сайті Верховної Ради України, під назвою «Законодавчо врегулювати канабіс для науки та медицини - захистити конституційні права громадян». У результаті вона стала поштовхом до того, що на рівні Верховної Ради розпочалася 
робота щодо врегулювання проблемних питань використання канабісу в медичних та наукових цілях [3].

На підставі сказаного, на нашу думку, цілком реальною може стати ситуація, коли вже найближчим часом перед органами державної влади постане питання щодо доцільності зміни розмірів канабісу, за дії з яким була б передбачена не кримінальна, а адміністративна відповідальність.

Аналіз останніх досліджень і публікацій. Питання кримінальної відповідальності за незаконне виробництво, виготовлення, придбання, зберігання, перевезення, пересилання чи збут наркотичних засобів, психотропних речовини або їх аналогів, кримінологічної характеристики та запобігання цим злочинам знайшли своє відображення в наукових працях таких учених, як: Ю. В. Баулін, А. А. Музика, І. О. Доброрез, О. П. Горох, В. А. Бублейник, В. М. Смітієнко, Є. В. Фесенко, Н. А. Мирошниченко, О.В.Козаченко, А. П. Закалюк та ін. Проте зміни, що мають місце останніми роками в Україні, у ставленні певної частини суспільства до цієї проблематики, переорієнтації державної політики щодо наркотичних засобів на нормативному рівні, світових тенденціях щодо регулювання обігу канабісу, обумовлюють актуальність та необхідність дослідження питання щодо доцільності збільшення ваги канабісу, за дії з яким була б передбачена адміністративна, а не кримінальна відповідальність. Проблематиці декриміналізації злочинів (кримінальних правопорушень) приділяли увагу О. О. Дудоров, М. І. Хавронюк, П. Л. Фріс, В. О. Туляков та інші. Теоретичним підгрунтям цієї статті щодо підстав та приводів декриміналізації стали праці П. Л. Фріса, О. О. Дудорова та М. І. Хавронюка $[6$, c. 67,$69 ; 7$, с. $65-68 ; 8$, c. 52-52].

Формування цілей. Метою цієї статті є аналіз підстав та приводів декриміналізації незаконного виробництва, виготовлення, придбання, зберігання, перевезення та пересилання канабісу без мети збуту за відсутності кваліфікуючих ознак, передбачених ч. ч. 2 та 3 ст. 309 КK України, та розробка пропозицій щодо вдосконалення меж кримінальноправового реагування на вказані дії 3 канабісом без мети збуту.

Виклад основного матеріалу. М. І. Хавронюк зазначає, що підставою декриміналізації будь-якого кримінального правопорушення $\epsilon$ його нездатність заподіювати істотну шкоду об'єктам кримінально-правової охорони, тобто втрата ним суспільної небезпечності. Під суспільною небезпечністю П. Л. Фріс розуміє властивість злочину (кримінального правопорушення) заподіювати тяжку шкоду існуючому в суспільстві правопорядку або ставить його під загрозу заподіяння такої шкоди. Суспільна небезпечність має два виміри: ступінь та характер. Характер суспільної небезпечності визначається суспільною цінністю об'єкта посягання, наслідками, способом вчинення злочину (кримінального правопорушення), мотивом i формою вини. Ступінь суспільної небезпечності - способом вчинення злочину (кримінального правопорушення) та розміром заподіяної шкоди. Важливим, на нашу думку, 
є також зауваження П. Л. Фріса стосовно того, що суспільна небезпечність є характеристикою не лише певного діяння, а й особи, яка його вчиняє.

У літературі підкреслюється динамічний характер суспільної небезпечності. Вона постійно здійснюється під впливом певних негативних чи позитивних факторів, які об'єктивно обумовлюють необхідність криміналізації (або навпаки декриміналізації) того чи іншого діяння. Указані фактори можуть бути негативним наслідком екологічних, демографічних змін, соціальних реформ тощо. Оскільки суспільна небезпечність з часом під впливом різних соціальних чинників може змінюватись, важливе значення мають приводи декриміналізації того чи іншого кримінального правопорушення. $\mathrm{y}$ літературі виділяються такі приводи до декриміналізації, як: а) необхідність виконання зобов'язань за міжнародними договорами, ратифікованими Верховною Радою України; б) необхідність створення правових механізмів утвердження й забезпечення прав і свобод людини як головного обов'язку держави; в) необхідність забезпечення реалізації певних положень законів; г) результати кримінологічних досліджень щодо динаміки та поширеності відповідного діяння; д) громадська думка. Для декриміналізації того чи іншого діяння не $є$ обов'язковою наявність всіх приводів, що наведені вище. Для обраної проблематики найбільше значення мають громадська думка та кримінологічні дослідження щодо поширеності й динаміки наркоманії та злочинності у сфері незаконного обігу наркотиків.

За останні десятиліття соціальні умови, у яких «існують» наркоманія та наркозлочинність, істотно змінилися. Масштаби незаконного обігу наркотиків та наркоманії в нашій державі є критичними. За даними МВС, в Україні офіційно нараховується близько 500 тис. наркоманів, із них понад 170 тис. регулярно вживають наркотики $[9$, с. 1]. Проте за методикою оцінки латентності немедичного вживання наркотиків, розробленого Міністерством охорони здоров'я згідно з міжнародними рекомендаціями, в умовах України число зареєстрованих осіб з немедичним споживанням наркотиків має бути збільшено в 5 разів проти облікового [10, с. 32], і в останні роки має дорівнювати близько 2,5 мільйони осіб (6 \% від усього населення (станом на 1 липня 2019 року чисельність населення України складала 42010,1 тис. осіб [11]). I всі ці особи є суб'єктами кримінальних правопорушень, передбачених ст. 309 КК України. Споживачами канабісу здебільшого є молоді люди віком до 35 років, часто із вищою освітою, які мають постійний дохід. Як правило, вони мають досвід вживання канабісу та «екстазі», інколи амфетамінів, а також галюциногенів, тобто наркотиків, що вживаються перорально та шляхом куріння [12, с. 163].

3 іншого боку, не викликає сумнівів той факт, що ступінь та характер суспільної небезпечності незаконного збуту наркотичних засобів, а також незаконного виробництва, виготовлення, придбання, зберігання, перевезення, пересилання канабісу з метою збуту є значно більшим та істотним у порівнянні $з$ діями, передбаченими ст. 309 ч. 1 КК України і за метою, і за суспільно небезпечними наслідками. У той же час статистичні дані про кількість облікованих злочинів у сфері незаконного обігу 
наркотичних засобів, психотропних речовин та їх аналогів, передбачених ст. 309 КК України та ст. 307 КК України, у 2013-2018 рр. [13] свідчать про те, що за останні роки (2016-2018 рр.) намітилася тенденція істотного збільшення питомої ваги злочинів, передбачених саме ст. 309 КК України. Якщо у 20132015 рр. співвідношення облікованих злочинів, передбачених ст. ст. 307 та 309 КК Украӥни, складало майже 1:2 відповідно (у середньому 8152 та 16766 злочини відповідно), то у 2016 році кількість облікованих за ст. 309 КК України злочинів перевищило аналогічний показник за ст. 307 КК України у 7,6 разів (17398 та 2293 злочини відповідно). У 2017-2018 рр. співвідношення зазначених злочинів складало майже 1:4 (у середньому 19047 та 5241 злочин відповідно).

Співвідношення кримінальних проваджень, направлених до суду 3 обвинувальним актом, за ст. ст. 307 та 309 КК України у 2013-2015 рр. також складало приблизно 1:2 (у середньому 5454 та 13028 проваджень відповідно). Проте в наступні роки мала місце ситуація, ще більш критична, ніж у співвідношенні відповідних облікованих злочинів. Так у 2016 році кримінальних проваджень за ст. 309 КК України було направлено у 15 разів більше, ніж за ст. 307 КК України (9 726 та 634 злочини відповідно), у 2017 та 2018 роках - у 5 разів більше (у середньому 2608 та 12615 проваджень відповідно).

Здійснений аналіз статистичних даних дозволяе нам зробити припущення, що по суті правоохоронні органи ведуть боротьбу переважно 3 тією частиною наркозлочинності, що має найменшу суспільну небезпеку зі споживачами наркотичних засобів, зокрема канабісу, які вчиняють певні дії $з$ канабісом задля власного вживання. Ті, хто є системоутворюючим елементом системи «наркозлочинність» і становить найбільшу суспільну небезпеку - торговці наркотичними засобами, - фактично залишаються поза межами кримінально-правового впливу. Існуючий підхід суперечить меті й завданням Стратегії державної політики щодо наркотиків на період до 2020 року.

Перейдемо до громадської думки як приводу декриміналізації того чи іншого кримінального правопорушення. Згідно зі списком 1 Таблиці I Переліку наркотичних засобів, психотропних речовин і прекурсорів, затвердженого постановою Кабінету Міністрів України № 770 від 6.05.2000 p. канабіс є особливо небезпечним наркотичним засобом. Натомість суспільна свідомість відносить його до «легких» наркотиків. І вже в цьому ми вбачаємо конфлікт між цінностями, що викладені в нормах права, і ставленням до них певної частини суспільства. Сама назва «легкі» наркотики може знімати психологічний бар'єр при прийнятті рішення щодо вживання канабісу в багатьох людей. Загальновідомим є факт, що в суспільній свідомості громадян не лише України, а й багатьох країн світу вживання канабісу, а, отже, і пов'язані з ним виготовлення, зберігання, перевезення та інші діяння (ст. 309 КК України), не асоціюються з діями, що мають велику суспільну небезпечність. 3 огляду на стрімке зростання споживачів наркотичних засобів, закономірною, на нашу думку, стає ситуація, за якої зростає кількість 
людей, що виступають за декриміналізацію діянь з канабісом без мети збуту в розмірах більших ніж 5 грамів.

Наведені дані вказують на серйозну соціальну проблему і в той же час наводять на думку, що наявність кримінальної відповідальності за незаконні дії 3 канабісом у розмірі вже від 5 грамів, передбачені ч.1 ст. 309 КК України, $€$ неефективним способом стримання росту споживачів цього наркотичного засобу. Існує нагальна потреба у вдосконаленні профілактичної роботи як зі споживачами, так і групами ризику, а також послабленні чинників наркоманії. А кримінально-правова політика у сфері обігу наркотичних засобів і канабісу зокрема потребує фактичного перегляду, оскільки жодні правоохоронні органи будь-якої країни не в змозі притягнути до кримінальної відповідальності 2,5 мільйони населення держави за діяння, пов'язані зі споживанням наркотичних засобів, у тому числі і за спрощеною процедурою, яка впроваджується Законом України «Про внесення змін до деяких законодавчих актів України щодо спрощення досудового розслідування окремих категорій кримінальних правопорушень» від 22.11.2018 року за діяннями, що підпадають під ознаки ч. 1 ст. 309 КК України.

Для визначення меж кримінально-правового реагування на обіг канабісу ключове значення має ознака «розмір наркотичного засобу канабіс». У Таблиці 1 «Невеликі, великі та особливо великі розміри наркотичних засобів, що знаходяться в незаконному обігу», затвердженій наказом Міністерства охорони здоров'я України №188 від 01.08.2000 p. (далі - Таблиці розмірів наркотичних засобів), для канабісу встановлено такі розміри: невеликі розміри - до 5 грамів, великі - від 500 до 2500 грамів, особливо великі - понад 2500 грамів. Придбання, зберігання, перевезення чи пересилання без мети збуту канабісу в розмірі до 5 грамів слід кваліфікувати за ст. 44 КУпАП; зазначені дії, а також виготовлення канабісу в розмірі від 5 до 500 грамів - за ч. 1 ст. 309 КК України. У Таблиці розмірів наркотичних засобів відсутній термін, який позначав би розмір наркотичного засобу між невеликими та великими розмірами (для канабісу - це від 5 до 500 грамів). У кримінально-правовій доктрині розмір наркотичного засобу між невеликими та великими розмірами позначається терміном «значні розміри» [див., наприклад: 14, с. 89]. У межах нашого дослідження необхідно диференціювати «значні розміри» канабісу. Під незначними розмірами ми пропонуємо позначати такі розміри канабісу, які було б доцільну декриміналізувати та перетворити на адміністративне правопорушення, передбачене ст. 44 КУпАП. Під значними розмірами ми пропонуємо розуміти розміри канабісу між незначними та великими розмірами, за незаконні дії 3 яким залишалась би кримінальна відповідальність. Введення терміну «незначні розміри», по-перше, дозволяе зберегти логіку законодавця, який у ст. 44 КУпАП та розділі ХІІІ Особливої частини КК України вживає саме якісні показники розмірів наркотичних засобів («у невеликих розмірах», «у великих розмірах», «в особливо великих розмірах»). 
Ми пропонуємо, щоб незначні розміри канабісу складали масу від 5 до 30 грамів і, відповідно, значні розміри - від 30 до 500 грамів. Слід зазначити, що існуюча світова практика кримінально-правового реагування на незаконний обіг канабісу [15] є досить різноманітною. Можна назвати країни, у яких розміри канабісу, за дії 3 якими настає кримінальна відповідальність, майже збігаються 3 відповідними розмірами в Україні (Литва - 5 грамів, Бельгія - навіть 3 грами), і є країни, які істотно «випереджають» нашу державу (Греція - 10 грамів, Германія - від 6 до 15 грамів, Португалія - 25 грамів, Нідерланди, Кипр - 30 грамів, Іспанія - 100 грамів). У деяких країнах (Польща, Естонія, Словенія, Словакія) відповідні розміри канабісу не встановлені і зазначені діяння відмежовуються за експертними висновками або на підставі юридичної практики. Україні належить удосконалювати власну наркополітику, яка $б$ враховувала зарубіжний досвід та вітчизняні соціальні реалії. Запропоноване нами верхнє порогове значення незначних розмірів канабісу від 5 грамів до саме 30 грамів, на нашу думку, носить дискусійний характер і потребує подальших наукових розвідок, як i питання щодо доцільності декриміналізації незаконних дій з канабісом у незначних розмірах (від 5 до 30 грамів) за наявності таких кваліфікуючих ознак, передбачених ч. ч. 2 та 3 ст. 309 КК України, як за попередньою змовою групою осіб; протягом року після засудження за ст. 309 КК України; із залученням неповнолітнього.

Висновки. Аналіз підстав та приводів декриміналізації виробництва, виготовлення, придбання, зберігання, перевезення, пересилання канабісу без мети збуту дозволяє дійти висновків, що на сьогодні ступінь суспільної небезпеки цих дій з канабісом у незначних розмірах має значно меншу суспільну небезпеку в порівнянні з аналогічними діями, що вчиняються 3 метою збуту. Проте зусилля правоохоронних органів України спрямовані на протидію менш суспільно небезпечним діянням за рахунок ресурсів, які мали б залучатись на розкриття більш суспільно небезпечних кримінальних правопорушень. Існуючий підхід суперечить принципу економії кримінально-правової репресії і прагматичній парадигмі кримінальноправового регулювання, а також меті й завданням Стратегії державної політики щодо наркотиків на період до 2020 року. Сучасний рівень вживання канабісу в Україні, а разом із ним і стан розповсюдженості незаконних виробництва, виготовлення, придбання, зберігання, перевезення та пересилання канабісу без мети збуту в незначних розмірах стають поширеними настільки, що боротьба з цими діяннями кримінальноправовими засобами стає неефективною і недоцільною. Пропонується віднести виробництво, виготовлення, придбання, зберігання, перевезення, пересилання без мети збуту в незначних розмірах до адміністративних правопорушень за відсутності таких кваліфікуючих ознак, передбачених ч. ч. 2 та 3 ст. 309 КК України, як вчинення цих дій за попередньою змовою групою осіб, із залученням неповнолітнього чи протягом року після засудження за ст. 309 КК України. 


\section{Використані джерела:}

1. Стратегія державної політики щодо наркотиків на період до 2010 року : Розпорядження Кабінету Міністрів України від 28.08.2013 № 735-р // База даних «Законодавство України» / Верховна Рада України. URL: http:/ /zakon.rada.gov.u a/laws/show/735-2013-\%D1\%80\#n8 (дата звернення: 10.12.2018).

2. Конопляний марш свободи-2017: декларація намірів. Марш свободи за зміни в державній політиці щодо наркотиків. URL: https:/ / marshsvobody.blogsp ot.com/2016/10/2017.html (дата звернення: 10.12.2018).

3. Відповідь на електронну петицію «Законодавчо врегулювати канабіс для науки та медицини - захистити конституційні права громадян» / Верховна Рада України : офіц. вебсайт. URL: https://itd.rada.gov.ua/services/Petition/Index/487 1?aname=responses (дата звернення: 10.12.2018).

4. Декриміналізація марихуани / MiyGolos.org.ua : oфіц. сайт: URL: https:/ / miygolos.org.ua/legal-zac-marihuani/show (дата звернення: 10.12.2018).

5.Електронні петиції / Офіційне інтернет-представництво Президента України: офіц. вебсайт. URL: https://petition.president.gov.ua/search? (дата звернення: 14.06.2019).

6. Правова доктрина України : у 5 т. Т. 5. Кримінально-правові науки в Україні: стан, проблеми та шляхи розвитку / За заг. ред. В.Я. Тація, В. І. Борисова; В. О. Навроцький, В. О. Туляков, М. І. Колос та ін.; передм. В. Я. Тація, В. І. Борисова. Харків : Видавництво «Право», 2013. 1240 с.

7. Дудоров О. О., Хавронюк М. І. Кримінальне право : навчальний посібник / За заг. ред. М.І. Хавронюка. Київ : Ваіте, 2014. 944 с.

8. Дудоров О. О. Криміналізація. Декриміналізація // Дудоров О. О. Кримі нальне право: теорія і практика (вибрані праці). Київ : Ваіте, 2017. С. 51-54.

9. Мокляк С. В. Кримінально-правова характеристика незаконного виробництва, виготовлення, придбання, зберігання, перевезення, пересилання чи збуту наркотичних засобів, психотропних речовин або їх аналогів, що вчиняються організованою групою : автореф. дис. ... канд. юрид. наук : 12.00.08. Київ, 2018. 20 с.

10. Наркозлочинність: кримінологічна характеристика та запобігання наук.навч. посібник / Інстит. вивч. пробл. Злочинності АПрН України; за ред. А. П. Закалюка; А. А. Бова, В. І. Женунтій, А. П. Закалюк, О. Г. Кулик та ін.; передм. А. П. Закалюка. Київ, 2006. 294 с.

11. Населення / Державна служба статистики України : офіц. вебсайт. URL: http:/ / www.ukrstat.gov.ua/ (дата звернення: 14.06.2019).

12. Національний звіт за 2017 рік щодо наркотичної ситуації в Україні (за даними 2016 року). Поглиблений огляд наркоситуації в Україні. Київ: Український моніторинговий та медичний центр з наркотиків та алкоголю міністерства охорони здоров'я України / уклад. Румянцева С. С., Ахмад Р. М., Бородін С.О. та ін. Київ, 2017. 176 c.

13. Статистична інформація про стан злочинності та результати прокурорсько-слідчої діяльності / Генеральна прокуратура України : офіц. вебсайт URL: https://www.gp.gov.ua/ua/statinfo.html (дата звернення: 24.11.2018).

14. Злочини у сфері обігу наркотичних засобів, психотропних речовин, їх аналогів або прекурсорів та інші злочини проти здоров'я населення: коментар до Розділу ХІІІ Кримінального кодексу України / С.В.Албул, А. М. Бабенко, О. А. Гритенко та ін.; за заг. ред. І.П. Катеринчука. Одеса : ОДУВС, 2018. 110 с. 
15. EU Drug Markets Report 2016. In-depth Analysis / European Monitoring Centre for Drugs and Drug Addiction, Europol. Luxembourg : Publications Office of the European Union, 2016. 190 p.

\section{References:}

1. Postanova Kabinetu Ministriv Ukrainy «Strategiia derzhavnoi polityky shchodo narkotykiv na period do 2020 roku» (n.d.). Zakon.rada.gov.ua. URL: http:/ / zakon.rada.gov.ua/laws/show/735-2013-\%D1\%80\#n8 [in Ukrainian].

2. Konoplianyi marsh svobody-2017: deklaratsiia namiriv. Marsh svobody za zminy v derzhavnii politytsi shchodo narkotykiv. URL: https://marshsvobody.blogspot .com/2016/10/2017.html. [in Ukrainian].

3. Ofitsiinyi vebsait Verkhovnoi Rady Ukrainy. Vidpovid na elektronnu petytsiiu «Zakonodavcho vreguliuvaty kanabis dlia nauky ta medytsyny - zachystyty konstytutsiini prava gromadian». Itd.rada.gov.ua. URL: https://itd.rada.gov.ua/services/Pe tition/Index/4871?aname=responses. [in Ukrainian].

4. Ofitsiinyi vebsait «MiyGolos.org.ua». Dekryminalizatsiia marykhuany. miygolos.org .ua. URL: https:/ / miygolos.org.ua/legal zac marihuani/show [in Ukrainian].

5. Ofitsiine internet-predstavnytstvo Prezydenta Ukrainy. Elektronni petytsii petition.president.gov.ua. URL: https:/ / petition.president.gov.ua/search? [in Ukrainian].

6. Navrotskii, V. O., Tuliakov, V. O., Kolos, M. I., Borisov, V. I., Fris, P.L. (et. al.). (2013). Kryminalno-pravovi nauky v Ukraini: stan, problemy ta shliachy rozvytku. Pravova doktryna Ukrayiny - The legal doctrine of Ukraine. Borisov, V. I., Tatsii, V. Ya. (Ed.). (Vols. 1-5). Kharkiv: Pravo. [in Ukrainian].

7. Dudorov, O. O., \& Khavroniuk, M. I. (2014). Kryminalne pravo-Criminal law. Kyiv: Vaite. [in Ukrainian].

8. Dudorov, O. O. (2017). Kryminalizatsiia. Dekryminalizatsiia. Kyiv: Vaite. [in Ukrainian].

9. Mokliak, S. V. (2018). Kryminalno-pravova kharakterystyka nezakonnogo vyrobnytstva, vygotovlennia, prydbannia, zberigannia, perevezennia, peresylannia chy zbutu narkotychnykh zasobiv, psykhotropnykh rechovyn abo yikh analogiv, shcho vchyniaiutsia organizovanoiu grupoiuю Extended abstract of candidate's thesis. Kyiv. [in Ukrainian].

10. Bova, A. A., Zhenuntii, V. I., Zakaliuk, A. P., Kulik, O. H., Myhailenko, P. P., \& Naumenko, A. V. (2006). Narkozlochynnist: kryminologichna kharakterystyka ta zapobigannia. Kyiv. [in Ukrainian].

11. Ofitsiinyi vebsait Derzhavnoi sluzhby statistiki Ukrainy. Naselennia. URL: http://www.ukrstat.gov.ua/ [in Ukrainian].

12. Rumiantseva, S. S., Akhmad, R. M., Borodin, S. O., Grynenko, M. I., Druzhynina, V. V., Zabolotko, V. M. et al. (2017). Natsionalnyi zvit za 2017 rik shchodo narkotychnoi sytuatsii v Ukraini (za danymy 2016 roku). Poglyblenyi ogliad narkosytuatsii v Ukraini. Kyiv. [in Ukrainian].

13. Ofitsinyi veb-sait Generalnoi prokuratury Ukrainy. Yedynyi zvit pro kryminalni pravoporushennia za sichen - gruden 2013 roku. URL: https:/ / www.gp.gov.ua /ua/statinfo.html. [in Ukrainian].

14. Albul, S. V., Babenko, A. M., Gritenko, O. A., Konopelskyi, V. Ya. \& Chekmarova, I. M. (2018). Zlochyny u sferi obigu narkotychnykh zasobiv, psykhotropnykh rechovyn, yikh analogiv abo prekursoriv ta inshi zlochyny proty zdorovia naselennia: komentar do Rozdilu XIII Kriminalnogo kodeksu Ukrainy. I. P. Katerynchuk (Ed.). Odesa: ODUVS. [in Ukrainian]. 
15. EU Drug Markets Report 2016. In-depth Analysis (2016) European Monitoring Centre for Drugs and Drug Addiction, Europol. Luxembourg: Publications Office of the European Union. [in English].

Стаття надійшла до редколегії 21.07.2019

Одинцова Е. В., кандидат юридических наук, старший преподаватель кафедры уголовно-правовых дисциплин Луганского государственного университета внутренних дел имени Э. А. Дидоренко (г. Северодонецк, Украина)

\section{К ВОПРОСУ О ДЕКРИМИНАЛИЗАЦИИ ОБОРОТА КАНАБИСА В НЕЗНАЧИТЕЛЬНЫХ РАЗМЕРАХ}

Статья посвящена анализу оснований и поводов декриминализации незаконного производства, изготовления, приобретения, хранения, перевозки и пересылки канабиса без цели сбыта при отсутствии квалифицирующих признаков, предусмотренных ч. ч. 2, 3 УК Украины.

Обосновывается позиция о том, что в современных условиях противодействие незаконному обороту канабиса без цели сбыта уголовно-правовыми средствами требует усовершенствования. Предлагается декриминализировать незаконные действия с канабисом без цели сбыта в незначительных размерах и предусмотреть за них административную ответственность по ст. 44 КУоАП при условии, что в действиях виновного лица отсутствуют такие квалифицирующие признаки, предусмотренные ч. ч. 2, 3 ст. 309 УК Украины, как совершение действий по предварительному сговору группой лищ; в течение года после осуждения по ст. 309 УК Украины; с задействованием несовершеннолетнего.

Ключевые слова: наркотические средства; оборот канабиса; канабис в незначительных размерах; незаконное производство, изготовление, приобретение, хранение, перевозка и пересылка канабиса без цели сбыта; декриминализация.

Odintsova O.,

Candidate of Law,

Senior teacher of the Department of Criminal Law disciplines

Lugansk State University of Internal Affairs of the named of E. O. Didorenko

(Sievierodonetsk, Ukraine)

\section{TO THE QUESTION FOR DECRIMINALIZATION OF CANNABIS TRAFFICKING IN INSIGNIFICANT AMOUNTS}

The article is devoted to the analysis of the grounds and reasons for the decriminalization of the illegal production, manufacture, acquisition, storage, transportation and shipment of cannabis without the purpose of sale in the absence of qualifying signs stipulated in Part 2, 3 of the Criminal Code of Ukraine.

Causes of decriminalization of criminal offenses in the sphere of drug trafficking are considered in detail: public opinion on the use of cannabis and the criminal law prohibition of these 
actions with cannabis; results of criminological research on the dynamics and prevalence of drug addiction and crime in the field of illicit drug trafficking.

The data obtained indicate the presence of a serious social problem and at the same time allow us to make the assumption that the existence of criminal responsibility for the illegal actions provided for by Part 1 of Art. 309 of the Criminal Code of Ukraine, in the amount of 5 grams, is not an effective way to curb the growth of consumers of this drug.

The position is substantiated that in modern conditions it is necessary not only to strengthen preventive work with drug users and risk groups, to reduce the factors of crime, but also to revise the criminal law policy in this area.

It is proposed to decriminalize the illegal production, manufacture, acquisition, storage, transportation and shipment of cannabis without the purpose of sale in insignificant amounts and provide for this administrative responsibility under Art. 44 of the Code of Ukraine on administrative offenses, provided that the actions of the guilty person do not have such qualifying signs, under Part 2, 3 of Art. 309 of the Criminal Code of Ukraine, as the commission of these actions by prior agreement by a group of persons or within a year after conviction under Art. 309 of the Criminal Code of Ukraine, or with the involvement of a minor.

Key words: drug; cannabis in insignificant amounts; illegal drug trafficking; illegal production, manufacturing, purchase, storage, transportation and shipment of cannabis without the purpose of sale; decriminalization. 